\title{
ESTUDO DE MANIFESTAÇÕES PATOLÓGICAS DO TERMINAL RODOVIÁRIO DE CRUZ DAS ALMAS - BA
}

\author{
Henrique Almeida Santana ${ }^{1}$ \\ Edvaldo Nascimento Conceição ${ }^{2}$ \\ Fernanda Nepomuceno Costa $^{3}$
}

Resumo: Patologia para a construção civil é entendido como a parte de engenharia que estuda os sintomas, causas e origens das lesões nas edificações. O Terminal Rodoviário da cidade de Cruz das Almas foi construído na década de oitenta, apresentando constante fluxo de veículos, com alta emissão de gás carbônico. Devido à aparência degradada da edificação, o presente trabalho teve como objetivo estudar as manifestações patológicas e determinar um prognóstico através de visita na edificação e revisão literária. As manifestações que predominam são as fissuras, manchas de umidade, segregação em peças de concreto e recalques. Os estudos mostraram que a edificação necessita de intervenções terapêuticas pertinente a manifestações patológicas, acompanhadas de profissionais habilitados.

Palavras-chave: Patologia; Terminal Rodoviário; construção.

\footnotetext{
1 Engenharia Civil/UFRB, Brasil. henrique_ufrb@hotmail.com.

2 Engenharia Civil/UFRB, Brasil. e.nasci.c@gmail.com.

3 Engenharia Civil/UFRB, Brasil. ferengcivil@yahoo.com.br.
} 